\title{
EFEKTIFITAS PENGGUNAAN MEDIA VIDEO DALAM PROSES KEGIATAN BELAJAR MENGAJAR MASA PANDEMI DI KELAS XI IPA3 SMA NEGERI 7 PONTIANAK
}

\author{
SAPRI \\ SMA Negeri 7 Pontianak \\ e-mail.sapri.ahmad2@gmail.com/sapri47@guru.sma.belajar.id
}

\begin{abstract}
ABSTRAK
Tujuan penelitian dengan menggunakan Media Video dalam proses mengajar di masa pandemi adalah untuk mengetahui keberhasilan kegiatan belajar dan hasil penilaian di masa Pandemi dengan menggunakan Penelitian Tindakan Kelas (PTK) yaitu siklus I dan Siklus II data yang diambil dalam penelitian berupa hasil observasi belajar siswa, yang dilakukan dengan bertahap-tahap mengalami peningkatan yang signifikan daripada siklus I pertemuan 1, 2 dan 3. Sedangkan pada penerapan siklus II pertemuan keempat rata-rata hasil belajar siswa terdapat $90 \%$ yang memperolah nilai yang tuntas sesuai KKM yang ada. Meningkatnya efektivitas siswa dalam proses pembelajaran juga berdampak pada meningkatnya pemahaman siswa terhadap materi yang diberikan. Hal ini dapat dilihat dari hasil belajar yang diberikan pada setiap akhir pembelajaran daring pada siswa yang mempu memperoleh nilai sesuai KKM.
\end{abstract}

Kata Kunci: Media Video, Belajar Mengajar, Masa Pandemi

\section{PENDAHULUAN}

COVID-19 pertama kali ditemukan di kota Wuhan, China pada akhir Desember 2019. Virus ini menular sangat cepat dan telah menyebar hampir ke semua negara, termasuk Indonesia, hanya dalam waktu beberapa bulan saja. Sehingga WHO pada tanggal 11 Maret 2020 menetapkan wabah ini sebagai pandemi global (I Gusti Agung Ayu Wulandari \& Gusti Ngurah Sastra Agustika, 2020:516). Pemerintah daerah memutuskan menerapkan kebijakan untuk meliburkan siswa dan mulai menerapkan metode belajar dengan sistem daring (dalam jaringan) atau online. Kebijakan pemerintah ini mulai efektif diberlakukan di beberapa wilayah provinsi pada hari Senin, 16 Maret 2020 yang juga diikuti oleh Provinsi Kalimantan Barat. Tetapi hal tersebut tidak berlaku bagi beberapa sekolah di daerah yang belum ada fasilitas internet. Sekolah-sekolah tersebut tidak siap dengan sistem pembelajaran daring, dimana membutuhkan media pembelajaran seperti handphone, laptop, atau computer.

Meskipun sekolah ditutup namun kegiatan belajar mengajar atau proses pembelajaran tidak berhenti, berdasarkan surat edaran menteri pendidikan dan kebudayaan bahwa seluruh kegiatan pembelajaran dilakukan dengan system pembelajaran dalam jaringan (daring) di rumah. Pembelajaran daring merupakan sebuah pembelajaran yang dilakukan dalam jarak jauh melalui media berupa internet dan alat penunjang lainnya seperti telepon seluler dan computer (Hilna Putria dkk (2020: 863).

Pembelajaran daring (dalam jaringan) adalah sistem pembelajaran dengan tidak tatap muka secara langsung antara guru dan siswa tetapi dilakukan melalui online yang menggunakan jaringan internet. Guru harus memastikan kegiatan belajar mengajar tetap 
berjalan, meskipun siswa berada di rumah. Maka solusinya adalah guru dituntut untuk dapat mendesain media pembelajaran sebagai inovasi dengan memanfaatkan media daring (online). Proses pembelajaran daring selama ini banyak dilakukan pemberian tugas melalui whatsapp, video conference, google form, ataupun melalui aplikasi khusus yang tersedia. Namun salah satu siswa mengaku lebih sering mendapatkan penugasan melalui whatsapp, lalu ditulis di buku dan difotokan untuk dikirim ke guru. Untuk kegiatan video conferencce juga dilakukan terjadwal, satu minggu dua kali untuk melakukan diskusi. Penugasan melalui aplikasi google form juga dilakukan, dimana setelah selesai mengerjakan tugas akan langsung muncul nilainya (Oktafia Ika Handarini \& Siti Sri Wulandari, 2020).

Hal ini sesuai dengan Menteri Pendidikan dan Kebudayaan Republik Indonesia terkait Surat Edaran Nomor 4 Tahun 2020 tentang Pelaksanaan Kebijakan Pendidikan dalam Masa Darurat Penyebaran Corona Virus Disease (COVID-19). Dari hasil pengamatan di SMA Negeri 7 Pontianak guru sudah dapat melakukan pembelajaran bersama diwaktu yang sama dengan menggunakan grup di media sosial seperti WhatsApp (WA) ataupun media lainnya sebagai media pembelajaran. Dengan demikian, guru dapat memastikan siswa mengikuti pembelajaran dalam waktu yang bersamaan, meskipun di tempat yang berbeda. Hal yang paling sederhana dapat dilakukan oleh guru bisa dengan memanfaatkan WhatsApp Group. Aplikasi WhatsApp cocok digunakan bagi pelajar daring pemula, karena pengoperasiannya sangat simpel dan mudah diakses siswa. Sedangkan bagi pengajar online yang mempunyai semangat yang lebih, bisa menngkatkan kemampuannya dengan menggunakan berbagai aplikasi pembelajaran daring.

Media online yang digunakan seperti youtube, whatsapp group, google classroom, dan quizzes. Materi diberikan dalam bentuk powerpoint, video singkat, dan bahan bacaan. Namun dalam pelaksanaan pembelajaran daring tersebut, perlu dilakukan evaluasi agar didapatkan langkah perbaikan jelas yang berbasis data. Hal itulah yang mendasari penulis untuk mengetahui gambaran efektivitas pembelajaran daring menggunakan media online (Mustakim, 2020: 3).

Dilihat media pembelajaran siswa maupun orangtua siswa yang tidak memiliki handphone untuk menunjang kegiatan pembelajaran daring ini, memang siswa merasa kebingungan, sehingga pihak sekolah ikut mencari solusi untuk mengantisipasi hal tersebut. Beberapa siswa yang tidak memiliki handphone, maka pembelajaran di lap komputer, dengan menjaga protocol kesehatan, sehingga siswa bisa melakukan aktivitas pembelajaran dengan difasilitasi oleh sekolah. Permasalahan yang terjadi bukan hanya terdapat pada sistem media pembelajaran akan tetapi ketersediaan kuota yang membutuhkan biaya cukup tinggi harganya bagi siswa dan guru guna memfasilitasi kebutuhan pembelajaran daring. Kuota yang dibeli untuk kebutuhan internet menjadi melonjak dan banyak diantara orangtua siswa yang tidak siap untuk menambah anggaran dalam menyediakan jaringan internet, maka sekolah menyediakan fasilitas kouta bagi siswa yang kurang mampu.

Banyak media sosial yang menceritakan pengalaman orangtua siswa selama mendampingi anak-anaknya belajar baik positif maupun negatif. Seperti misalnya ternyata ada orangtua yang sering marah-marah karena mendapatkan anaknya yang sulit diatur sehingga mereka tidak tahan dan menginginkan anak mereka belajar kembali di 
sekolah. Kejadian ini memberikan kesadaran kepada orangtua bahwa mendidik anak itu ternyata tidak mudah, diperlukan ilmu dan kesabaran yang sangat besar. Sehingga dengan kejadian ini orangtua harus menyadari dan mengetahui bagaimana cara membimbing anak-anak mereka dalam belajar. Setelah mendapat pengalaman ini diharapkan para orangtua mau belajar bagaimana cara mendidik anak-anak mereka di rumah.

Perlu disadari bahwa ketidaksiapan guru dan siswa terhadap pembelajaran daring juga menjadi masalah. Perpindahan sistem belajar konvensional ke sistem daring amat mendadak, tanpa persiapan yang matang. Tetapi semua ini harus tetap dilaksanakan agar proses pembelajaran dapat berjalan lancar dan siswa aktif mengikuti walaupun dalam kondisi pandemi Covid-19. Terjadinya wabah ini ada sebuah pelajaran yang dipetik dari dunia pendidikan, yaitu kegiatan belajar tatap muka dengan guru terbukti lebih efektif ketimbang secara daring (online). Hal tersebut dipaparkan oleh pakar pendidikan Universitas Brawijaya (UB) Aulia Luqman Aziz bertepatan dengan Hari Pendidikan Nasional 2020. "Selamanya profesi guru tidak akan tergantikan oleh teknologi" papar Luqman dalam keterangannya di Kompas 2020/05/04.

Beberapa guru di SMAN 7 Pontianak mengaku, jika pembelajaran daring ini tidak seefektif kegiatan pembelajaran konvensional (tatap muka langsung), karena beberapa materi harus dijelaskan secara langsung dan lebih lengkap. Selain itu materi yang disampaikan secara daring belum tentu bisa dipahami semua siswa. Berdasarkan pengalaman mengajar secara daring, sistem ini hanya efektif untuk memberi penugasan kepada siswa. Maka perlunya media video dalam pembelajaran daring.

\section{METODE PENELITIAN}

Prosedur Penelitian Tindakan Kelas (PTK) dapat dilaksanakan melalui empat langkah utama yaitu: perencanaan (planning), pelaksanaan (acting), pengamatan (observing) dan refleksi (reflecting). Empat langkah utama dalam pelaksanaan Penelitan Tindakan Kelas (PTK) sering disebut dengan istilah satu siklus (Susilo, Herawati.dkk, 2009:19). Untuk lebih jelas berikut ini dikemukakan model siklus Penelitian Tindakan Kelas (PTK): 

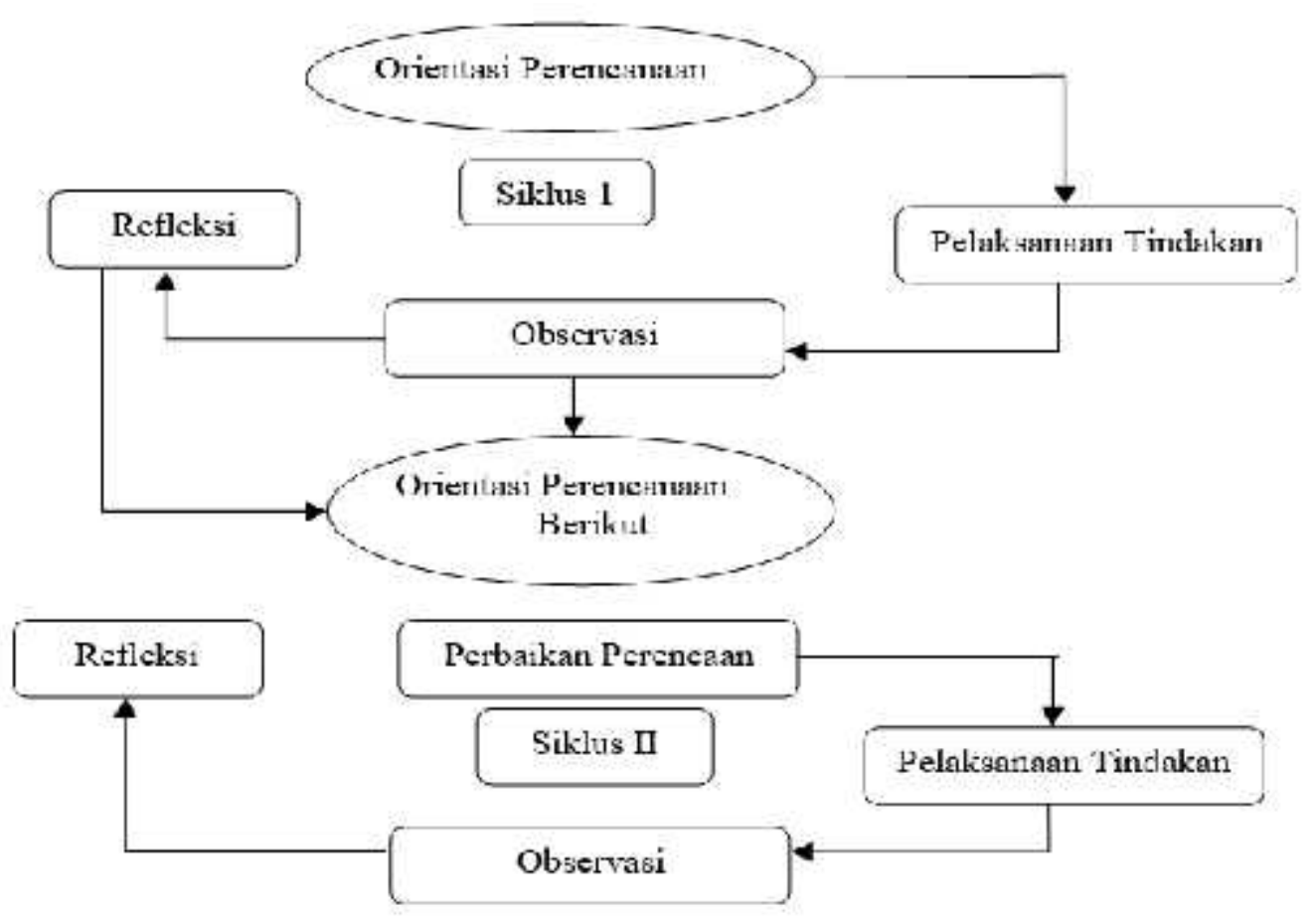

Gambar 1. Model siklus Penelitian Tindakan Kelas (PTK)

Hasil observasi dianalisis dengan analisis deskriptif berdasarkan hasil observasi dan refleksi dengan indikator kinerja peserta didik dalam pembelajaran. Adapun Indikator kinerja peserta didik dalam pembelajaran dapat dibuat dalam bentuk tabel sebagai berikut:

Tebel Indikator Kinerja

\begin{tabular}{|l|c|l|}
\hline \multicolumn{1}{|c|}{ Aspek } & \multicolumn{1}{|c|}{$\begin{array}{c}\text { Indikator } \\
\text { Keberhasilan (\%) }\end{array}$} & \multicolumn{1}{c|}{ Alat Ukur } \\
\hline $\begin{array}{l}\text { Aktivitas siswa dalam } \\
\text { pembelajaran media video } \\
\text { masa pandemi }\end{array}$ & $75 \%$ & $\begin{array}{l}\text { Menggunakan format } \\
\text { observasi aktivitas belajar } \\
\text { siswa dengan } \\
\text { menggunakan media video } \\
\text { masa pandemi. }\end{array}$ \\
\hline $\begin{array}{l}\text { Aktivitas guru dalam } \\
\text { menggunakan model } \\
\text { pembelajaran media video } \\
\text { masa pandemi }\end{array}$ & $75 \%$ & $\begin{array}{l}\text { Menggunakan format } \\
\text { observasi aktivitas guru } \\
\text { dalam menerapkan media } \\
\text { video masa pandemi. }\end{array}$ \\
\hline $\begin{array}{l}\text { Hasil belajar siswa pada mata } \\
\text { pelajaran PAI dengan } \\
\text { menggunakan media video } \\
\text { masa pandemi. }\end{array}$ & $75 \%$ & $\begin{array}{l}\text { Menggunakan tes hasil } \\
\text { belajar. }\end{array}$ \\
\hline
\end{tabular}




\section{HASIL PENELITIAN DAN PEMBAHASAN}

\section{Hasil Penelitian Siklus I}

Hasil observasi aktivitas siswa dalam proses pembelajaran pada petemuan 1 Selasa, 21 Juli 2020 menggunakan media web pada tabel sebagai berikut:

Tabel 1. Observasi Aktivitas Siswa dalam Proses Pembelajaran siklus I Pertemuan pertama

\begin{tabular}{|c|c|c|c|}
\hline No & Nama Siswa & $\begin{array}{c}\text { Mengerjakan } \\
\text { Tugas Nilai }\end{array}$ & $\begin{array}{c}\text { Tidak Mengerjakan } \\
\text { tugas }\end{array}$ \\
\hline 1 & Agung Laksono Putra & $65.00 / 100$ & - \\
\hline 2 & Aulia Arta Anggraeni & - & A \\
\hline 3 & Benny Siswono & $55.00 / 100$ & - \\
\hline 4 & Cyrena Azalia Ika Prasasti & $55.00 / 100$ & - \\
\hline 5 & Dimas Aditya Irawan & $75.00 / 100$ & - \\
\hline 6 & Diva Putri Amanda & $75.00 / 100$ & - \\
\hline 7 & Duta satria Nugraha & - & $\mathrm{A}$ \\
\hline 8 & Fatia Nazwa & $80.00 / 100$ & - \\
\hline 9 & Heni Hemalia Putri & $70.00 / 100$ & - \\
\hline 10 & Jorti Erfian Shandu & $60.00 / 100$ & - \\
\hline 11 & Kevin Surya Nugraha Teneh & $60.00 / 100$ & - \\
\hline 12 & Lata Mustika Lagita & $65.00 / 100$ & - \\
\hline 13 & Mari Artameivia Putri & - & A \\
\hline 14 & Melvi Maulia & $60.00 / 100$ & - \\
\hline 15 & Miranda & $80.00 / 100$ & - \\
\hline 16 & Muhammad Nugraha Naufal & $60.00 / 100$ & - \\
\hline 17 & Muhammad Rafli Nurhakim & $65.00 / 100$ & - \\
\hline 18 & Muhammad Thariq Fathurra & $80.00 / 100$ & - \\
\hline 19 & Nafilah Nursyawalia & $75.00 / 100$ & - \\
\hline 20 & Nazwa Cahaya & $85.00 / 100$ & - \\
\hline 21 & Nurul Faniya & $70.00 / 100$ & - \\
\hline 22 & Oktavia Triani & - & A \\
\hline 23 & Patricia Vivi & $80.00 / 100$ & - \\
\hline 24 & Radhika Salsabila & $70.00 / 100$ & - \\
\hline 25 & Rangga Permana & $70.00 / 100$ & - \\
\hline 26 & Ryca Mazaya Ramadhani & $75.00 / 100$ & - \\
\hline \multirow[t]{2}{*}{27} & Salma Nur Salsabila & 65.0100 & - \\
\hline & Rata-rata & 65,00 & 4 \\
\hline
\end{tabular}

Dari tabel di atas dapat diketahui aktivias siswa dalam proses pembelajarana masih belum maksimal karena ada 4 siswa yang masih Alfa. Dan belum mencapai keberhasilan pembelajaran seperti yang diharapkan. Hal ini dapat dilihat dari rincian penjelasan tabel sebagai berikut: Terdapat 8 orang siswa yang tuntas atau 29,6\% dan 19 orang siswa yang tidak tuntas atau 70,4\%. Atau rata-rata nilai $65 \%$.

Hasil observasi aktivitas siswa dalam proses pembelajaran pada petemuan 2 Selasa, 18 Agustus 2020 masih menggunakan media web pada tabel sebagai berikut: 
Tabel 2. Observasi Aktivitas Siswa dalam Proses Pembelajaran siklus I Pertemuan kedua

\begin{tabular}{|c|c|c|c|}
\hline No & Nama Siswa & $\begin{array}{c}\text { Mengerjakan } \\
\text { Tugas Nilai }\end{array}$ & $\begin{array}{c}\text { Tidak Mengerjakan } \\
\text { tugas }\end{array}$ \\
\hline 1 & Agung Laksono Putra & $65.00 / 100$ & - \\
\hline 2 & Aulia Arta Anggraeni & $65.00 / 100$ & - \\
\hline 3 & Benny Siswono & $75.00 / 100$ & - \\
\hline 4 & Cyrena Azalia Ika Prasasti & $75.00 / 100$ & - \\
\hline 5 & Dimas Aditya Irawan & $75.00 / 100$ & - \\
\hline 6 & Diva Putri Amanda & $75.00 / 100$ & - \\
\hline 7 & Duta satria Nugraha & $70.00 / 100$ & - \\
\hline 8 & Fatia Nazwa & $80.00 / 100$ & - \\
\hline 9 & Heni Hemalia Putri & $70.00 / 100$ & - \\
\hline 10 & Jorti Erfian Shandu & $60.00 / 100$ & - \\
\hline 11 & Kevin Surya Nugraha Teneh & - & $\mathrm{A}$ \\
\hline 12 & Lata Mustika Lagita & $65.00 / 100$ & - \\
\hline 13 & Mari Artameivia Putri & $60.00 / 100$ & - \\
\hline 14 & Melvi Maulia & $60.00 / 100$ & - \\
\hline 15 & Miranda & $80.00 / 100$ & - \\
\hline 16 & Muhammad Nugraha Naufal & $60.00 / 100$ & - \\
\hline 17 & Muhammad Rafli Nurhakim & - & A \\
\hline 18 & Muhammad Thariq Fathurra & $80.00 / 100$ & - \\
\hline 19 & Nafilah Nursyawalia & $75.00 / 100$ & - \\
\hline 20 & Nazwa Cahaya & $88.00 / 100$ & - \\
\hline 21 & Nurul Faniya & $70.00 / 100$ & - \\
\hline 22 & Oktavia Triani & $70.00 / 100$ & - \\
\hline 23 & Patricia Vivi & $80.00 / 100$ & - \\
\hline 24 & Radhika Salsabila & $70.00 / 100$ & - \\
\hline 25 & Rangga Permana & $70.00 / 100$ & - \\
\hline 26 & Ryca Mazaya Ramadhani & - & A \\
\hline 27 & Salma Nur Salsabila & 66.0100 & - \\
\hline & Rata-rata & 68,00 & 3 \\
\hline
\end{tabular}

Berdasarkan paparan data dari tabel di atas bahwa masih ada siswa yang tidak akti dalam pembelajaran ada 3 siswa yang masih Alfa. Dari hasil belajar siswa siklus pertama (tabel. 2) pertemuan kedua di atas, mengindikasikan bahwa penguasaan peserta didik terhadap materi pelajaran masih tergolong kurang yaitu terdapat 10 orang siswa yang tuntas atau $37 \%$ dan 17 orang siswa yang tidak tuntas atau $70 \%$. Atau rata-rata nilai $68 \%$.

\section{Hasil Penelitian Siklus II}

Hasil observasi aktivitas siswa dalam proses pembelajaran pada petemuan 3 Selasa, 08 September 2020 menggunakan media video pada tabel sebagai berikut: 
Tabel 3. Observasi Aktivitas Siswa dalam Proses Pembelajaran siklus II Pertemuan ketiga

\begin{tabular}{|c|c|c|c|}
\hline No & Nama Siswa & $\begin{array}{c}\text { Mengerjakan } \\
\text { Tugas Nilai }\end{array}$ & $\begin{array}{c}\text { Tidak Mengerjakan } \\
\text { tugas }\end{array}$ \\
\hline 1 & Agung Laksono Putra & $80.00 / 100$ & - \\
\hline 2 & Aulia Arta Anggraeni & $85.00 / 100$ & - \\
\hline 3 & Benny Siswono & $80.00 / 100$ & - \\
\hline 4 & Cyrena Azalia Ika Prasasti & $80.00 / 100$ & - \\
\hline 5 & Dimas Aditya Irawan & - & A \\
\hline 6 & Diva Putri Amanda & $80.00 / 100$ & - \\
\hline 7 & Duta satria Nugraha & $75.00 / 100$ & - \\
\hline 8 & Fatia Nazwa & $80.00 / 100$ & - \\
\hline 9 & Heni Hemalia Putri & $80.00 / 100$ & - \\
\hline 10 & Jorti Erfian Shandu & $80.00 / 100$ & - \\
\hline 11 & Kevin Surya Nugraha Teneh & $84.00 / 100$ & - \\
\hline 12 & Lata Mustika Lagita & $85.00 / 100$ & - \\
\hline 13 & Mari Artameivia Putri & $80.00 / 100$ & - \\
\hline 14 & Melvi Maulia & $80.00 / 100$ & - \\
\hline 15 & Miranda & $80.00 / 100$ & - \\
\hline 16 & Muhammad Nugraha Naufal & $80.00 / 100$ & - \\
\hline 17 & Muhammad Rafli Nurhakim & $80.00 / 100$ & - \\
\hline 18 & Muhammad Thariq Fathurra & $80.00 / 100$ & - \\
\hline 19 & Nafilah Nursyawalia & $80.00 / 100$ & - \\
\hline 20 & Nazwa Cahaya & $93.00 / 100$ & - \\
\hline 21 & Nurul Faniya & $80.00 / 100$ & - \\
\hline 22 & Oktavia Triani & $85.00 / 100$ & - \\
\hline 23 & Patricia Vivi & $85.00 / 100$ & - \\
\hline 24 & Radhika Salsabila & $84.00 / 100$ & - \\
\hline 25 & Rangga Permana & $85.00 / 100$ & - \\
\hline 26 & Ryca Mazaya Ramadhani & $85.00 / 100$ & - \\
\hline \multirow[t]{2}{*}{27} & Salma Nur Salsabila & $85.00 / 100$ & - \\
\hline & Rata-rata & 84,00 & 0 \\
\hline
\end{tabular}

Hasil observasi aktivitas peserta didik dalam proses pembelajaran pada siklus II mengalami peningkatan. Akan tetapi masih ada siswa yang tidak aktif melakukan pembelajaran Daring yaitu 1 siswa, Hal ini dapat dilihat dari penjelasan sebagai berikut:

1. Pada siklus 2 pertemuan ke tiga $100 \%$ siswa tuntas dengan menggunakan media video. Namun pada siklus kedua pertemuan ketiga nilai rata-rata $84 \%$, belum mencapai target yaitu $90 \%$. Masih ada siswa yang tidak aktif.

2. Dari aspek keaktifan siswa pada kehadiran dan dalam mengerjakan tugas, pada siklus 2 pertemuan ketiga masih ada siswa yang tidak aktif dalam pembelajaran Daring, walaupun 1 siswa itu artinya ada kemajuan dari segi aktivitas siswa. Hal ini karena: 
a) Wali kelas dan guru memberikan motivasi pada siswa agar lebih aktif dalam pembelajaran Daring.

b) Lebih intensif membimbing siswa terutama bagi siswa yang mengalami kesulitan dalam pembelajaran Daring

c) Memberikan penghargaan (reward) bagi yang rajin absen dan mengerjakan tugas dalam proses pembelajaran siklus pertama.

Hasil observasi aktivitas siswa dalam proses pembelajaran pada petemuan 4 Selasa, 06 Oktober 2020 masih menggunakan media video pada tabel sebagai berikut:

Tabel 4. Observasi Aktivitas Siswa dalam Proses Pembelajaran siklus II Pertemuan keempat

\begin{tabular}{|c|c|c|c|}
\hline No & Nama Siswa & $\begin{array}{c}\text { Mengerjakan } \\
\text { Tugas Nilai }\end{array}$ & $\begin{array}{c}\text { Tidak Mengerjakan } \\
\text { tugas }\end{array}$ \\
\hline 1 & Agung Laksono Putra & $88.00 / 100$ & - \\
\hline 2 & Aulia Arta Anggraeni & $90.00 / 100$ & - \\
\hline 3 & Benny Siswono & $90.00 / 100$ & - \\
\hline 4 & Cyrena Azalia Ika Prasasti & $90.00 / 100$ & - \\
\hline 5 & Dimas Aditya Irawan & $90.00 / 100$ & - \\
\hline 6 & Diva Putri Amanda & $86.00 / 100$ & - \\
\hline 7 & Duta satria Nugraha & $90.00 / 100$ & - \\
\hline 8 & Fatia Nazwa & $86.00 / 100$ & - \\
\hline 9 & Heni Hemalia Putri & $90.00 / 100$ & - \\
\hline 10 & Jorti Erfian Shandu & $88.00 / 100$ & - \\
\hline 11 & Kevin Surya Nugraha Teneh & $92.00 / 100$ & - \\
\hline 12 & Lata Mustika Lagita & $90.00 / 100$ & - \\
\hline 13 & Mari Artameivia Putri & $90.00 / 100$ & - \\
\hline 14 & Melvi Maulia & $93.00 / 100$ & - \\
\hline 15 & Miranda & $90.00 / 100$ & - \\
\hline 16 & Muhammad Nugraha Naufal & $90.00 / 100$ & - \\
\hline 17 & Muhammad Rafli Nurhakim & $88.00 / 100$ & - \\
\hline 18 & Muhammad Thariq Fathurra & $90.00 / 100$ & - \\
\hline 19 & Nafilah Nursyawalia & $88.00 / 100$ & - \\
\hline 20 & Nazwa Cahaya & $95.00 / 100$ & - \\
\hline 21 & Nurul Faniya & $88.00 / 100$ & - \\
\hline 22 & Oktavia Triani & $90.00 / 100$ & - \\
\hline 23 & Patricia Vivi & $90.00 / 100$ & - \\
\hline 24 & Radhika Salsabila & $92.00 / 100$ & - \\
\hline 25 & Rangga Permana & $90.00 / 100$ & - \\
\hline 26 & Ryca Mazaya Ramadhani & $93.00 / 100$ & - \\
\hline \multirow[t]{2}{*}{27} & Salma Nur Salsabila & $90.00 / 100$ & - \\
\hline & Rata-rata & 90,00 & 0 \\
\hline
\end{tabular}

Dari tabel di atas, dapat diketahui bahwa hasil belajar yang dilakukan pada siklus II pertemuan keempat mengalami peningkatan yang signifikan daripada siklus I 
pertemuan 1, 2 dan 3. Sedangkan pada penerapan siklus II pertemuan keempat rata-rata hasil belajar siswa terdapat $90 \%$ yang memperolah nilai yang tuntas sesuai KKM yang ada. Hal ini mengindikasikan bahwa hasil belajar pada siklus II pertemuan keempat mengalami peningkatan yang signifikan dan telah melebihi skor ideal yang telah ditentukan dalam indikator penelitian yaitu $75 \%$.

\section{Pembahasan Penelitian}

Media pembelajaran daring tidak menuntut siswa untuk hadir di kelas. Siswa dapat mengakses pembelajaran melalui media internet. Penggunaan teknologi yang tersedia disekitar kita apabila diimbangi dengan diskusi dan panduan maka akan menjadi alat pengembangan keterampilan berpikir tingkat tinggi (Hamdani, A. R., \& Priatna, A, 2020). Perkembangan teknologi ini memudahkan penggunaan internet untuk mengakses materi pembelajaran, berinteraksi dengan konten, instruktur, dan pelajar lain dan untuk mendapatkan dukungan selama proses belajar, untuk memperoleh pengetahuan, untuk membangun pribadi makna, dan tumbuh dari pengalaman belajar. Umumnya, setiap guru dapat memiliki pertimbangan sendiri untuk memilih media pembelajaran mana yang dianggap paling cocok untuk diselenggarakan pada pembelajaran Daring yang dilakukan sekarang ini. Fitriyani, Y., Fauzi, I., \& Sari, M. Z (2020) bahwa Pembelajaran daring menjadi sebuah solusi untuk mengatasi masalah yang dihadapi oleh sekolah dalam sistem pendidikan, dengan memberikan penjelasan dan pembelajaran yang baik dan jelas, maka siswa dapat melaksanakan pembelajaran daring dengan efisien dan lebih maksimal. Pembelajaran secara daring dianggap menjadi solusi terbaik terhadap kegiatan pembelajaran di tengah pandemi Covid-19.

Efektivitas penggunaan media video dalam proses kegiatan belajaran mengajar PAI di Masa Pandemi di Kelas XI IPA3 menunjukkan keberhasilan dan terus mengalami peningkatan pembelajaran. Hal ini dapat dilihat dari data observasi aktivitas siswa yang dilaksanakan sebagai berikut:

\section{Siklus I Pertemuan 1}

Dari hasil observasi yang dilakukan dapat diketahui aktivias siswa dalam proses pembelajarana masih belum maksimal karena ada 4 siswa yang masih Alfa. Dan belum mencapai keberhasilan pembelajaran seperti yang diharapkan. Hal ini dapat dilihat dari rincian observasi yang dilakukan yaitu Terdapat 8 orang siswa yang tuntas atau 29,6\% dan 19 orang siswa yang tidak tuntas atau 70,4\%. Atau rata-rata nilai $65 \%$.

\section{Siklus I Pertemuan 2}

Berdasarkan hasil observasi yang dilakukan pada pertemuan ke 2 bahwa masih ada siswa yang tidak akti dalam pembelajaran ada 3 siswa yang masih Alfa. Dari hasil belajar siswa siklus pertama (tabel. 2) pertemuan kedua, mengindikasikan bahwa penguasaan peserta didik terhadap materi pelajaran masih tergolong kurang yaitu terdapat 10 orang siswa yang tuntas atau $37 \%$ dan 17 orang siswa yang tidak tuntas atau $70 \%$. Atau rata-rata nilai $68 \%$

Adapun hasil refleksi siklus I pertemuan 1 dan pertemuan 2 dapat dipaparkan sebagai berikut:

1. Sebagian siswa belum terbiasa dengan kondisi belajar Daring dengan menggunakan media web Hal ini bisa dilihat dari hasil observasi aktivitas siswa yang masih banyak tidak efektif. 
2. Hasil belajar siklus pertama pertemuan 1 hanya $29,6 \%$ siswa yang memperoleh nilai di bawah KKM. Hal ini tentu belum mencapai kategori keberhasilan indikator yang ditetapkan yaitu $75 \%$.

3. Hasil belajar siklus pertama pertemua 2 hanya $30 \%$ siswa yang memperoleh nilai di bawah KKM. Hal ini tentu belum mencapai kategori keberhasilan indikator yang ditetapkan yaitu $75 \%$.

\section{Siklus II Pertemuan 3}

Hasil observasi aktivitas peserta didik dalam proses pembelajaran pada siklus II mengalami peningkatan. Akan tetapi masih ada siswa yang tidak aktif melakukan pembelajaran Daring yaitu 1 siswa, Hal ini dapat dilihat dari penjelasan sebagai berikut:

1. Pada siklus 2 pertemuan ke tiga $100 \%$ siswa tuntas dengan menggunakan media video. Namun pada siklus kedua pertemuan ketiga nilai rata-rata 84\%, belum mencapai target yaitu 90\%. Masih ada siswa yang tidak aktif.

2. Dari aspek keaktifan siswa pada kehadiran dan dalam mengerjakan tugas, pada siklus 2 pertemuan ketiga masih ada siswa yang tidak aktif dalam pembelajaran Daring, walaupun 1 siswa itu artinya ada kemajuan dari segi aktivitas siswa. Hal ini karena: (1) Wali kelas dan guru memberikan motivasi pada siswa agar lebih aktif dalam pembelajaran Daring (2) Lebih intensif membimbing siswa terutama bagi siswa yang mengalami kesulitan dalam pembelajaran Daring (3) Memberikan penghargaan (reward) bagi yang rajin absen dan mengerjakan tugas dalam proses pembelajaran siklus pertama.

\section{Siklus II Pertemuan 4}

Dari hasil observasi, dapat diketahui bahwa hasil belajar yang dilakukan pada siklus II pertemuan keempat mengalami peningkatan yang signifikan daripada siklus I pertemuan 1, 2 dan 3. Sedangkan pada penerapan siklus II pertemuan keempat rata-rata hasil belajar siswa terdapat $90 \%$ yang memperolah nilai yang tuntas sesuai KKM yang ada. Hal ini mengindikasikan bahwa hasil belajar pada siklus II pertemuan keempat mengalami peningkatan yang signifikan dan telah melebihi skor ideal yang telah ditentukan dalam indikator penelitian yaitu $75 \%$.

Adapun keberhasilan yang diperoleh selama siklus II adalah sebagai berikut:

1. Aktivitas siswa dalam proses pembelajaran sudah mengarah ke pembelajaran media video. Hal ini tergambar dalam (1) siswa mampu membangun kedisiplinan dalam kegiatan belajar Daring (2) siswa sudah memahami tugas yang diberikan oleh guru dan mulai mampu berpartisipasi dalam kegiatan dan tepat waktu dalam pelaksanaan pembelajaran Daring.

2. Meningkatnya aktivitas siswa dalam proses pembelajaran didukung oleh meningkatnya aktivitas guru dalam mempertahankan dan meningkatkan suasana pembelajaran efektif dalam kegiatan pembelajaran Daring. Guru intensif membimbing siswa dalam yang mengalami kesulitan dalam pembelajaran Daring.

3. Meningkatnya aktivitas siswa dalam proses pembelajaran juga berimplikasi pada meningkatnya pemahaman siswa terhadap materi yang diberikan. Hal ini dapat dilihat dari hasil evaluasi yang diberikan pada setiap akhir pembelajaran. Yang mana pada siklus pertama rata-rata nilai hasil belajar mencapai $29 \%$, belum memperoleh nilai sesuai KKM. sedangkan pada siklus II hasil evaluasi akhir mencapai $86.67 \%$ siswa yang mempu memperoleh nilai sesuai KKM. 
Hasil penelitian tersebut di atas, mengalami peningkatan dalam proses pebelajaran karena fungsi media pembelajaran sangat mendukung terutama pada masa pandemi sekarang ini. Hal ini sejalan dengan Ahmad Saberi (2010: 133) bahwa fungsi pokok penggunaan media dalam pembelajaran Antara lain:

1) Penggunaan media dalam proses pembelajaran mempunyai fungsi tersendiri sebagai alat bantu untuk mewujudkan situasi belajar mengajar yang efektif.

2) Penggunaan media merupakan bagian yang integral dari keseluruhan situasi mengajar. ini berarti bahwa media merupakan salah satu unsur yang harus dikembangkan guru.

3) Media dalam penggunaannya integral dengan tujuan dan fungsi ini mengandung makna bahwa media harus melihat kepada tujuan dan bahan pelajaran.

4) Penggunaan media dalam pembelajaran bukan semata-mata alat hiburan, dalam arti digunakan hanya sekedar melengkapi proses supaya lebih menarik perhatian siswa.

5) Penggunaan media dalam pembelajaran dapat membantu untuk mempercepat proses pembelajaran dan membantu siswa dalam menangkap pengertian dan pemahaman dari proses pembelajaran yang diberikan guru.

6) Penggunaan media dalam pembelajaran diutamakan untuk meningkatkan dan mempertinggi mutu belajar.

\section{KESIMPULAN}

Meningkatnya efektivitas siswa dalam proses pembelajaran juga berdampak pada meningkatnya pemahaman siswa terhadap materi yang diberikan. Hal ini dapat dilihat dari hasil belajar yang diberikan pada setiap akhir pembelajaran daring pada siswa yang mempu memperoleh nilai sesuai KKM. Hasil belajar yang dilakukan bertahap-tahap mengalami peningkatan yang signifikan daripada siklus I pertemuan 1, 2 dan 3 . Sedangkan pada penerapan siklus II pertemuan keempat rata-rata hasil belajar siswa terdapat $90 \%$ yang memperolah nilai yang tuntas sesuai KKM yang ada. Hal ini mengindikasikan bahwa hasil belajar pada siklus II pertemuan keempat mengalami peningkatan yang signifikan dan telah melebihi skor ideal yang telah ditentukan dalam indikator penelitian yaitu $75 \%$.

\section{DAFTAR PUSTAKA}

Ahmad Saberi (2010) Strategi Belajar Mengajar. Jakarta: Quantum Teaching Djam'an, S \& Ann ,K. (2012) Metode Penelitian Kualitatif. Bandung: Alfabeta.

Fitriyani, Y., Fauzi, I., \& Sari, M. Z. (2020). Motivasi Belajar Mahasiswa Pada Pembelajaran Daring Selama Pamdemic Covid-19. Jurnal Kependidikan, 6 (2)

Hilna Putria dkk (2020) Analisis Proses Pembelajaran Dalam Jaringan (DARING) Masa Pandemi COVID-19 pada Guru Sekolah Dasar. Jurnal Basicedu Volume 4 Nomor 4 Tahun Halm. 861 - 872.

Hamdani, A. R., \& Priatna, A. (2020). Efektivitas Implementasi Pembelajaran Daring (Full Online) Dimasa Pandemi Covid-19. Jurnal VI, 1-9.

Kompas (2020) Belajar dari Covid-19, Pakar UB: Peran Guru Tidak Terganti Teknologi Online at https://edukasi.kompas.com/read/2020/05/04/140605771/belajar-dari- 
covid-19-pakar-ub-peran-guru-tidak-terganti-teknologi?page=all Accessed 20 Oktober 2020.

Mahmud \& Tedi Priatna (2008) Penelitian Tindakan Kelas Teori dan Praktik. Bandung: Tsabita.

Mustakim (2020) Efektivitas Pembelajaran Daring Menggunakan Media Online selama Pandemi Covid-19 pada Mata Pelajaran Matematika. Al asma: Journal of Islamic Education Vol. 2, No. 1.

Oktafia, I., H., \& Siti, S., W., (2020) Pembelajaran Daring Sebagai Upaya Study From Home (SFH) Selama Pandemi Covid 19. Jurnal Pendidikan Administrasi Perkantoran (JPAP) Volume 8, Nomor 3

Shofan Hariyanto (2020). Pelatihan Editing Video Pembelajaran Dengan Kinemaster. Ikatan Guru Indonesia (IGI) Kerja Sama dengan Jaringan Sekolah Digital Indonesia (JSDI) dan Narasi.

Susilo, Herawati dkk (2009). Penelitian Tindakan Kelas Sebagai Sarana Keprofesionalan Guru dan Calon Guru. Malang: Bayumedia 